\title{
Origin and evolution of a submarine large igneous province: the Kerguelen Plateau and Broken Ridge, southern Indian Ocean
}

F.A. Frey ${ }^{\mathrm{a}, *}$, M.F. Coffin ${ }^{\mathrm{b}}$, P.J. Wallace ${ }^{\mathrm{c}}$, D. Weis ${ }^{\mathrm{d}}$, X. Zhao ${ }^{\mathrm{e}}$, S.W. Wise Jr. ${ }^{f}$, V. Wähnert ${ }^{g}$, D.A.H. Teagle ${ }^{\text {h }}$, P.J. Saccocia ${ }^{\mathrm{i}}$, D.N. Reusch ${ }^{\mathrm{j}}$, M.S. Pringle ${ }^{\mathrm{k}}$, K.E. Nicolaysen ${ }^{\mathrm{a}}$, C.R. Neal ${ }^{1}$, R.D. Müller ${ }^{\mathrm{m}}$, C.L. Moore ${ }^{\mathrm{n}}$, J.J. Mahoney ${ }^{o}$, L. Keszthelyi ${ }^{p}$, H. Inokuchi ${ }^{q}$, R.A. Duncan ${ }^{r}$, H. Delius ${ }^{\mathrm{s}}$, J.E. Damuth ${ }^{\mathrm{t}}$, D. Damasceno ${ }^{\mathrm{d}}$, H.K. Coxall ${ }^{\mathrm{u}}$, M.K. Borre ${ }^{\mathrm{v}}$, F. Boehm ${ }^{\mathrm{w}}$, J. Barling ${ }^{\mathrm{x}}$, N.T. Arndt ${ }^{\mathrm{y}}$, M. Antretter $\mathrm{z}$

a Deptartment of Earth, Atmospheric and Planetary Sciences, Massachusetts Institute of Technology, 77 Massachusetts Ave., Cambridge, MA 02139, USA

b Institute for Geophysics, University of Texas at Austin, 4412 Spicewood Springs Road, Bldg. 600, Austin, TX 78759-8500, USA c Ocean Drilling Program, Texas A and M University, 1000 Discovery Drive, College Station, TX 77845, USA

d Dépt. des Sciences de la Terre et de L'Environnement, Université Libre de Bruxelles, C.P. 160/02, Avenue F.D. Roosevelt 50, Bruxelles 1050, Belgium

e Institute of Tectonics and Earth Sciences Department, University of California, 1156 High Street, Santa Cruz, CA 95064, USA

f Department of Geology, 4100, Florida State University, Carraway Bldg., Tallahassee, FL 32306-4100, USA g Museum für Naturkunde, Institut für Paläontologie, Invalidenstr. 43, Berlin 10115, Germany

h School of Ocean and Earth Science, Southampton Oceanography Centre, University of Southampton, Southampton SO14-3ZH, UK

i Department of Earth Sciences and Geography, Bridgewater State College, Bridgewater, MA 02325, USA

j Department of Geological Sciences, University of Maine, 5790 Bryand Global Sciences Center, Orono, ME 04469-5790, USA

k Scottish Universities Research and Reactor Centre, Scottish Enterprise Technology Park, East Kilbride, Glasgow G75 0QF, UK

${ }^{1}$ Department of Civil Engineering and Geological Sciences, 156 Fitzpatrick Hall, University of Notre Dame, Notre Dame, IN 46556, USA

m School of Geosciences, Division of Geology and Geophysics, University of Sydney, Building F05, Sydney, N.S.W. 2006, Australia n CRC LEME, University of Canberra, ACT 2601, Canberra, N.S. W., Australia

o School of Ocean and Earth Science and Technology, Department of Geology and Geophysics, University of Hawaii at Manoa, 2525 Correa Road, Honolulu, HI 96822, USA

p Lunar and Planetary Laboratory, University of Arizona, Tucson, AZ 85721, USA

q School of Humanity for Environment Policy and Technology, Himeji Institute of Technology, Shinzaikehonmachi 1-1-12, Himeji, Hyogo 670-0092, Japan

r College of Oceanic and Atmospheric Sciences, Oregon State University, Oceanography Administration Building 104, Corvallis, OR 97331-5503, USA

s Angewandte Geophysik, Rheinisch-Westfälische Technische Hochschule Aachen, Lochnerstr. 4-20, Aachen 52056, Germany

${ }^{\mathrm{t}}$ Department of Geology, University of Texas at Arlington, P.O. Box 19049, Arlington, TX 76019-0049, USA

u Department of Geology, University of Bristol, Wills Memorial Building, Queens Rd., Bristol BS8 1RJ, UK

v Department of Geology and Geotechnical Engineering, Technical University of Denmark, Building 204, DK-2800 Lyngby, Denmark w GEOMAR, Wischhofstr. 1-3, D-24248 Kiel, Germany

\footnotetext{
* Corresponding author. Tel.: +1-617-253-2127; Fax: +1-617-253-8298; E-mail: fafrey@mit.edu
} 
x Department of Earth and Environmental Sciences, University of Rochester, Hutchison Hall 227, Rochester, NY 14627, USA
y LGCA, Institut Dolomieu, 15, rue Maurice Gignoux, Grenoble Cedex 38031, France
z Institut für Allgemeine und Angewandte Geophysik, Ludwig-Maximilians-Universität München, Theresienstr. 41, Munich 80333,
Germany

Received 11 June 1999; accepted 10 December 1999

\begin{abstract}
Oceanic plateaus form by mantle processes distinct from those forming oceanic crust at divergent plate boundaries. Eleven drillsites into igneous basement of Kerguelen Plateau and Broken Ridge, including seven from the recent Ocean Drilling Program Leg 183 (1998-99) and four from Legs 119 and 120 (1987-88), show that the dominant rocks are basalts with geochemical characteristics distinct from those of mid-ocean ridge basalts. Moreover, the physical characteristics of the lava flows and the presence of wood fragments, charcoal, pollen, spores and seeds in the shallow water sediments overlying the igneous basement show that the growth rate of the plateau was sufficient to form subaerial landmasses. Most of the southern Kerguelen Plateau formed at $\sim 110 \mathrm{Ma}$, but the uppermost submarine lavas in the northern Kerguelen Plateau erupted during Cenozoic time. These results are consistent with derivation of the plateau by partial melting of the Kerguelen plume. Leg 183 provided two new major observations about the final growth stages of the Kerguelen Plateau. 1: At several locations, volcanism ended with explosive eruptions of volatilerich, felsic magmas; although the total volume of felsic volcanic rocks is poorly constrained, the explosive nature of the eruptions may have resulted in globally significant effects on climate and atmospheric chemistry during the late-stage, subaerial growth of the Kerguelen Plateau. 2: At one drillsite, clasts of garnet-biotite gneiss, a continental rock, occur in a fluvial conglomerate intercalated within basaltic flows. Previously, geochemical and geophysical evidence has been used to infer continental lithospheric components within this large igneous province. A continental geochemical signature in an oceanic setting may represent deeply recycled crust incorporated into the Kerguelen plume or continental fragments dispersed during initial formation of the Indian Ocean during breakup of Gondwana. The clasts of garnet-biotite gneiss are the first unequivocal evidence of continental crust in this oceanic plateau. We propose that during initial breakup between India and Antarctica, the spreading center jumped northwards transferring slivers of the continental Indian plate to oceanic portions of the Antarctic plate. (c) 2000 Published by Elsevier Science B.V. All rights reserved.
\end{abstract}

Keywords: Kerguelen Plateau; Broken Ridge; igneous rocks; geochemistry; explosive eruptions; Ocean Drilling Program; continental crust

\section{Introduction}

Large igneous provinces (LIPs) are constructed when copious amounts of mantle-derived magma enter the Earth's crust in localized regions. This type of volcanism differs in style, location and geochemical characteristics from volcanism at divergent plate boundaries (mid-ocean ridge spreading centers) and convergent plate boundaries (arc volcanoes associated with plate subduction). Many LIPs formed during Cretaceous time. The two most voluminous LIPs are Cretaceous oceanic plateaus, Ontong Java in the Pacific Ocean and Kerguelen Plateau/Broken Ridge in the southern Indian Ocean (Fig. 1). They cover vast areas $\left(\sim 2 \times 10^{6} \mathrm{~km}^{2}\right)$, stand $2-4 \mathrm{~km}$ above the surrounding ocean floor and have thick mafic crusts of $20-40 \mathrm{~km}$ compared to the typical oceanic crustal thickness of $7 \mathrm{~km}[1,2]$. This intense igneous activity, perhaps reflecting a more vigorous mode of whole mantle convection than the present [3], temporarily increased the flux of material and energy from the mantle to the crust, hydrosphere, biosphere and atmosphere. Possible consequences are global environmental changes involving climate, sea level, oceanic anoxia, seawater composition and biological radiations and extinctions.

The Cretaceous Kerguelen Plateau/Broken Ridge LIP is interpreted to represent voluminous 


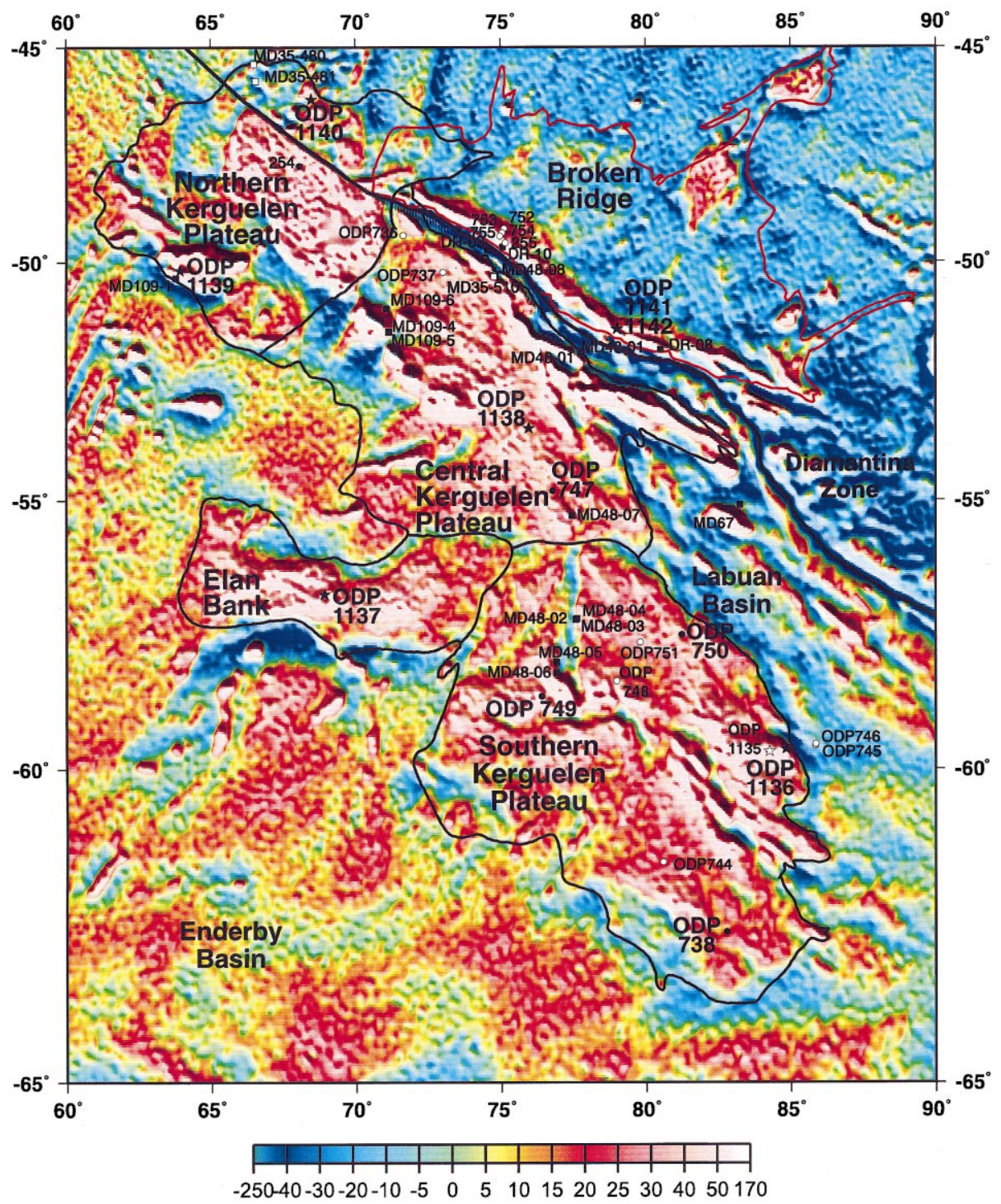

\section{$\mathrm{mGal}$}

Fig. 1. Plate reconstruction of the Kerguelen Plateau and Broken Ridge free-air gravity field [67] at C18n.2n (40.1 Ma) using rotation poles of [68] Kerguelen Plateau sector boundaries are outlined in black. Leg 183 drill sites ( $\star$ ), Leg 119/120 drill sites (circles) and dredge or piston core locations (squares) where igneous basement was recovered are in black; where only sediment was penetrated, the symbols are white.

volcanism associated with arrival of the Kerguelen plume head below young Indian Ocean lithosphere (Fig. 2) [4-6]. Subsequently, rapid northward movement of the Indian plate over the plume stem formed a $5000 \mathrm{~km}$ long, $\sim 82-38$ Ma, hot spot track, the Ninetyeast Ridge [7,8].
At $\sim 40 \mathrm{Ma}$, the newly formed Southeast Indian Ridge (SEIR) intersected the plume's position. As the SEIR migrated northeast relative to the plume, hot spot magmatism became confined to the Antarctic plate. From $\sim 40 \mathrm{Ma}$ to the present, the Kerguelen Archipelago, Heard and 

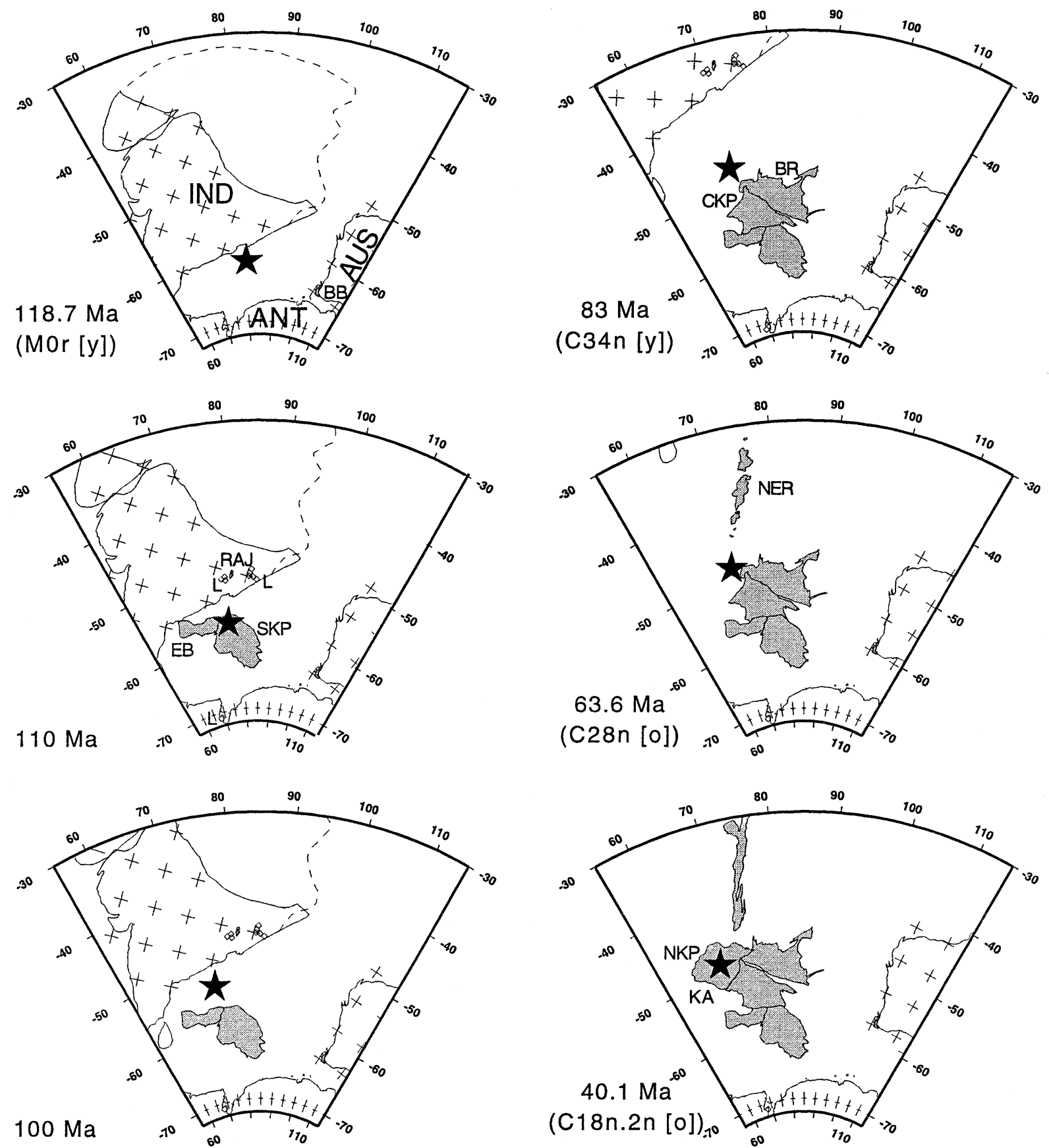

McDonald Islands, and a northwest-southeast trending chain of submarine volcanoes between these islands were constructed on the northern and central sectors of the Kerguelen Plateau (Figs. 1 and 2). Thus, a $\sim 110$ Ma record of volcanism is attributed to the Kerguelen plume [4-8].

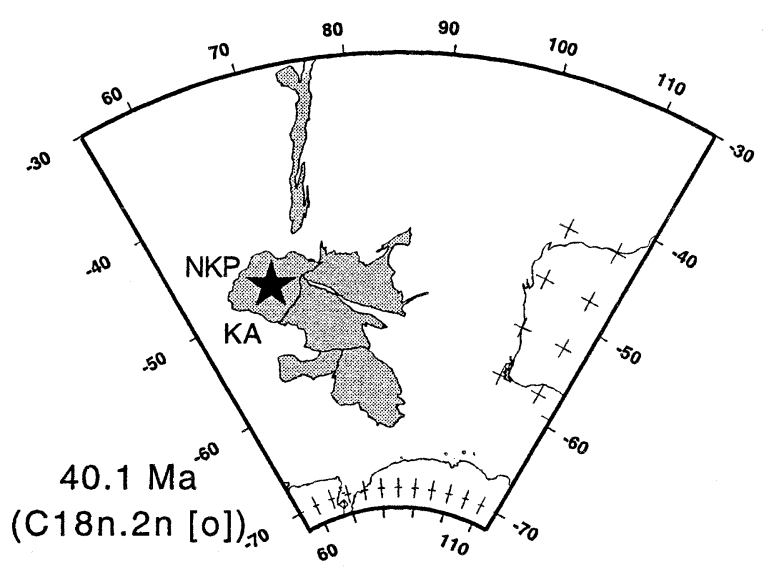

Despite the huge size of some oceanic plateaus and their potential role in contributing to our understanding of Cretaceous mantle circulation and environmental change, they are among the least understood features in the ocean basins. The igneous crust of the Kerguelen Plateau and 
Fig. 2. Plate reconstructions of the southern Indian Ocean region using a hot spot reference frame [68]; Antarctica is fixed. Reconstructed position of the Kerguelen hot spot (after [69]) is indicated by black stars. Volcanic rock associated with the Kerguelen hot spot is indicated in light stipple (blue) and lamprophyres as diamonds, as they have appeared through geologic time. Dashed line indicates a possible northern boundary for Greater India. IND: India; ANT: Antarctica; AUS: Australia. 118.7 $\left(M 0 r_{y}\right) \quad M a$ : Seafloor spreading initiated during chron M11 $(\approx 133 \mathrm{Ma})$ between western Australia and Greater India [70]; a minimum estimate for the initiation of seafloor spreading between Australia and Antarctica is slightly later at $\approx 125 \mathrm{Ma}$ [71]. Between 130.9 and $118.7 \mathrm{Ma}$, Antarctica migrates to the SE relative to the Kerguelen hot spot. 110 and $100 \mathrm{Ma}$ : Seafloor spreading continues among India, Antarctica and Australia. The first massive pulse of Kerguelen magmatism creates the SKP at $\approx 110 \mathrm{Ma}$ and possibly Elan Bank (EB), as Indian Ocean lithosphere migrates SE relative to the Kerguelen hot spot. 83 (C34ny) and 63.6 $\left(C 28 n_{o}\right) \mathrm{Ma}$ : India continues its northward drift relative to Antarctica, and the Kerguelen hot spot is predicted to have remained close to the NE edge of the central Plateau (CKP) and Broken Ridge (BR), which form at $\sim 85-95$ Ma. Subsequently, the hot spot generates the Ninetyeast Ridge (NER). 40.1 (C18n.2no) $M a$ : At $\approx 40$ Ma, seafloor spreading commences between the CKP and Broken Ridge. The hot spot generates the NKP, and since $40 \mathrm{Ma}$, as Broken Ridge and the Kerguelen Plateau continue to separate, produces the Kerguelen Archipelago (KA), Heard and McDonald Islands, and the chain of volcanoes between KA and Heard Island (Fig. 1).

$\leftarrow$

Broken Ridge have been sampled by dredging and drilling; in particular, the 1998-99 Ocean Drilling Program Leg 183 focused on the development of this LIP in time and space by drilling and coring five holes into igneous crust of the Kerguelen Plateau and two into Broken Ridge (Figs. 1 and 3). We find that much of the southern and central Kerguelen Plateau (SKP and CKP) formed subaerial landmasses whose surfaces range in age from $\sim 110 \mathrm{Ma}$ in the south to perhaps $\sim 85$ $\mathrm{Ma}$ in the central part of the plateau. In contrast, the uppermost lavas of the northern Kerguelen Plateau (NKP) are Cenozoic. At three Leg 183 drillsites, plateau construction ended with explosive eruption of highly evolved felsic magmas that may have had significant environmental consequences. At drillsite 1137, clasts of garnet-biotite gneiss in a fluvial conglomerate interbedded with basalt flows show that continental rocks were exposed on Elan Bank (Fig. 1).

\section{Kerguelen Plateau/Broken Ridge: background}

The Kerguelen Plateau is a broad (200-600 km wide) topographic high, in the southern Indian Ocean, extending for $\sim 2300 \mathrm{~km}$ between $46^{\circ} \mathrm{S}$ and $64^{\circ} \mathrm{S}$ (Fig. 1). It is divided into distinct domains: the SKP, CKP and NKP; Elan Bank; and the Labuan Basin (Fig. 1). Multichannel seismic reflection data show that numerous dipping intrabasement reflections interpreted as subaerial flood basalts form the uppermost igneous crust of the Kerguelen Plateau $[9,10]$.
The SKP, at water depths of $1.5-2 \mathrm{~km}$, has experienced multiple stages of normal faulting, graben formation, and strike-slip faulting [1116]. The $\sim 22 \mathrm{~km}$ thick igneous crust consists of three layers: an upper crustal layer $\sim 5.3 \mathrm{~km}$ thick with velocities ranging from 3.8 to $6.5 \mathrm{~km} /$ $\mathrm{s}$; a lower crustal layer $\sim 11 \mathrm{~km}$ thick with velocities of $6.6-6.9 \mathrm{~km} / \mathrm{s}$; and a $4-6 \mathrm{~km}$ thick, seismically reflective transition zone at the base of the crust characterized by velocities of $6.7-6.9 \mathrm{~km} / \mathrm{s}$ $[17,18]$. Such a transition zone at the crust-mantle interface has not been imaged on the CKP or NKP, and forms the basis for the hypothesis that parts of the SKP contain fragments of continental crust [17,18].

The CKP with water depths similar to the SKP includes the volcanically active Heard and McDonald Islands. The igneous crust is $19-21 \mathrm{~km}$ thick and consists of three layers. The upper layer is $1.2-2.3 \mathrm{~km}$ thick and velocities range from 3.8 to $4.9 \mathrm{~km} / \mathrm{s}$. The middle layer is $2.3-3.3 \mathrm{~km}$ thick and velocities increase downward from 4.7 to 6.7 $\mathrm{km} / \mathrm{s}$. In the $\sim 17 \mathrm{~km}$ thick lower crust, velocities increase from $6.6 \mathrm{~km} / \mathrm{s}$ at $\sim 8.0 \mathrm{~km}$ depth to 7.4 $\mathrm{km} / \mathrm{s}$ at the base of the crust with no internal discontinuity [19]. The CKP and Broken Ridge formed as a single entity; subsequently, at $\sim 40$ Ma, Broken Ridge and the CKP began to separate along the nascent SEIR [20]. Broken Ridge, now $\sim 1800 \mathrm{~km}$ north of the Kerguelen Plateau, is a narrow and elongated oceanic plateau (100$200 \mathrm{~km}$ by $\sim 1000 \mathrm{~km}$ at $\sim 2 \mathrm{~km}$ water depth) that trends west-northwest. Broken Ridge's southern flank was uplifted, perhaps more than 
$2000 \mathrm{~m}$, during the Early Tertiary separation from the Kerguelen Plateau [21].

Elan Bank, a salient extending westward from the boundary between the CKP and SKP, has water depths from $<1000$ to $2000 \mathrm{~m}$. Labuan Basin, which adjoins the CKP and SKP to the east, is deep $(>3500 \mathrm{~m})$, extensively faulted and thickly sedimented $(>2000 \mathrm{~m}$ assuming a sediment seismic velocity of $2000 \mathrm{~m} / \mathrm{s}$ ). Dredging of a faulted basement block in the Labuan Basin recovered metamorphic and granitic rock, but these rocks have been interpreted as ice-rafted debris [22], so the nature of the basin's crust (i.e. oceanic or continental) is uncertain.

The NKP, dominantly at water depths $<1 \mathrm{~km}$, includes the Kerguelen Archipelago. Wide-angle seismic data from the archipelago show an upper igneous crust $8-9.5 \mathrm{~km}$ thick, with velocities of $4.6-6.2 \mathrm{~km} / \mathrm{s}$, and a lower crust $6-9.5 \mathrm{~km}$ thick, with a velocity of $6.8 \mathrm{~km} / \mathrm{s}[19,23,24]$.

\section{Summary of age variation}

Previous dating of basalts recovered at four spatially diverse locations on the SKP (ODP Sites 738, 749 and 750, and dredge site MD48-05, Fig. 1) has shown that the uppermost igneous crust formed over a relatively short interval at $\sim 110$ Ma ([25-28] and Fig. 3). Middle Albian ( 104.5$106.5 \mathrm{Ma})$ shallow water sands and clays overlying basaltic flows recovered from Site 1136 (Fig. 3) also support a $\sim 110 \mathrm{Ma}$ age for the SKP. In contrast, basement basalts from Site 747 on the CKP may be much younger, $\sim 85 \mathrm{Ma}[28,29]$. This age is similar to the $83-88 \mathrm{Ma}$ age for lavas from Broken Ridge dredge sites 8 and 10 [8], which were close to Site 747 prior to separation between Broken Ridge and the CKP (Figs. 1 and 2). Also, piston coring of sediments on the northeast flank of the CKP between the Kerguelen Archipelago and Heard Island (MD35-510 in Fig. 1) recovered cherts and calcareous oozes of probable Santonian age (83.5-85.5 Ma) [29]. Site 1138 basalts from the CKP are overlain by CenomanianTuronian ( $94 \mathrm{Ma}$ ) sandstone (Fig. 3). The first recovery of igneous basement from Elan Bank was at Site 1137; basement is overlain by late
Campanian ( $75 \mathrm{Ma}$ ) packstone (Fig. 3). Igneous basement is likely to be somewhat older, as the packstone is at the top of a basal sedimentary sequence that thickens markedly to the east of Site 1137. These sparse data show that most of the Kerguelen Plateau and Broken Ridge formed in Cretaceous time, but the SKP is distinctly older than the CKP and Broken Ridge.

In contrast, Cenozoic magmatism $(\sim 40 \mathrm{Ma}$ to present) has formed the NKP and Kerguelen Archipelago, as well as numerous volcanic edifices on the Cretaceous CKP: Heard and McDonald Islands, and the bathymetric/gravity highs between the Kerguelen Archipelago and Heard Island [30-35]. The first recovery of submarine igneous basement from the NKP was at Site 1139 on Skiff Bank and Site 1140 on the northernmost Kerguelen Plateau (Fig. 1). On Skiff Bank, chalk at the base of the pelagic sedimentary section is earliest Oligocene (32.8-34.3 Ma) in age (Fig. 3). This minimum age is consistent with the oldest rocks ( $\sim 38 \mathrm{Ma})$ from the Kerguelen Archipelago [30]. At Site 1140, pelagic sediment of late Eocene age $(\sim 35 \mathrm{Ma})$ is intercalated with basalt flows (Fig. 3).

\section{Eruption environment}

Evidence from basalts and overlying sediments at Sites 738, 747, 748, 749 and 750 (Fig. 1), combined with results of subsidence modeling, has shown previously that much of the igneous crust of the SKP and CKP was erupted in a subaerial environment [36]. Portions of the SKP remained subaerial for as much as $50 \mathrm{Ma}$ after volcanism ceased. The new Leg 183 drilling results corroborate, extend and add detail to these conclusions (Fig. 3). At SKP Site 1136, upper bathyal to neritic sediments overly inflated pahoehoe lavas which lack features of submarine volcanism (e.g. pillows and quenched glassy margins) suggesting subaerial eruption. The CKP Site 1138 was above sea level during the final stages of construction; subaerial pyroclastic flow deposits overly subaerial lava flows that include both aa and inflated pahoehoe types. Terrestrial and shallow marine sediments containing wood fragments, seeds, 


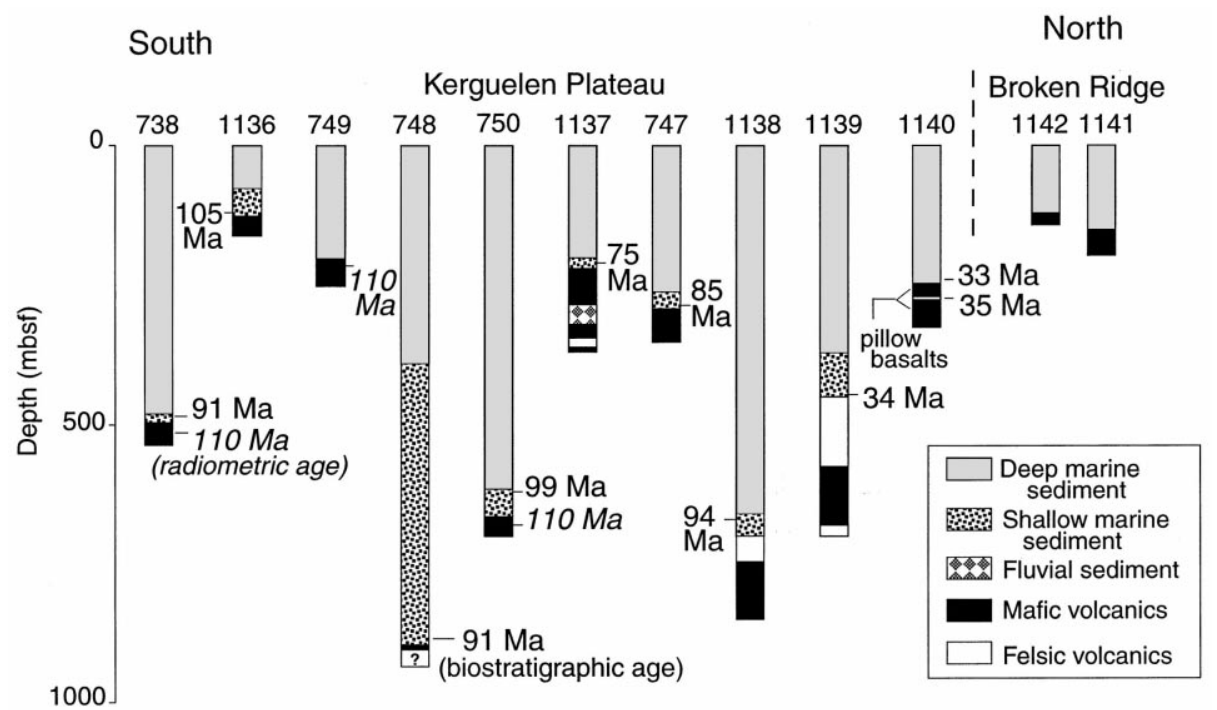

Fig. 3. Summary of ODP drill holes on the Kerguelen Plateau that recovered volcanic rocks. Data are shown for Leg 119 (Site 738), Leg 120 (Sites 747, 748, 749 and 750) and Leg 183 (Sites 1136, 1137, 1138, 1139, 1140, 1141 and 1142). Multichannel seismic reflection profiles indicate that the volcanic rocks at all sites except Site 748 were recovered from the uppermost basement of the plateau, which lies beneath younger sedimentary cover. Basalt at Site 748 was recovered $\sim 200 \mathrm{~m}$ above the seismically defined basement and overlies a poorly recovered zone that contains smectitic clay and highly altered basalt. Radiometric ages for basalts [25-28] are shown in italics. Biostratigraphic ages of sediments overlying basement are also indicated. Data sources are as seen in EPSL Online Background Data Set $^{1}$.

spores and pollen overly igneous basement, documenting that the CKP was subaerial after volcanism ceased. The vesicularity and oxidative alteration of basement basalts at Broken Ridge Sites 1141 and 1142 which formed close to the CKP (Fig. 2) are also consistent with a subaerial environment.

The igneous basement complex of Elan Bank (Site 1137) includes basaltic lava flows that were erupted subaerially, as indicated by oxidation zones and inflated pahoehoe lava flows. Some interbedded volcaniclastic rocks were deposited in a fluvial environment (braided river), consistent with subaerial eruption of the basalts (Fig. 3). Gradual subsidence of Elan Bank is shown by the upward succession of intercalated subaerial basalt flows and fluvial sediments, neritic packstones and pelagic oozes.

Skiff Bank on the NKP (Site 1139) was also

\footnotetext{
${ }^{1}$ http://www.elsevier.nl/locate/epsl; mirror site: http://www. elsevier.com/locate/epsl
}

subaerial during its final stages of formation, as indicated by a succession of variably oxidized volcanic and volcaniclastic rocks. After volcanism ceased, paleoenvironments of the overlying sediments changed from intertidal (beach deposits) to very high-energy, near-shore (grainstone and sandstone) to low-energy, offshore (packstone) to bathyal pelagic (ooze). In contrast, igneous basement at Site 1140 at the northernmost edge of the NKP consists entirely of pillow basalts and intercalated pelagic sediment.

\section{Post-melting magma evolution}

Tholeiitic basalt is the dominant lava type forming the upper tens of meters of the igneous crust of the Kerguelen Plateau (Fig. 4). Tholeiitic basalts are the major component of continental flood basalts and large oceanic islands such as Iceland and the Hawaiian Islands. Such magmas are expected when a mantle plume of relatively hot peridotite partially melts during ascent. The 


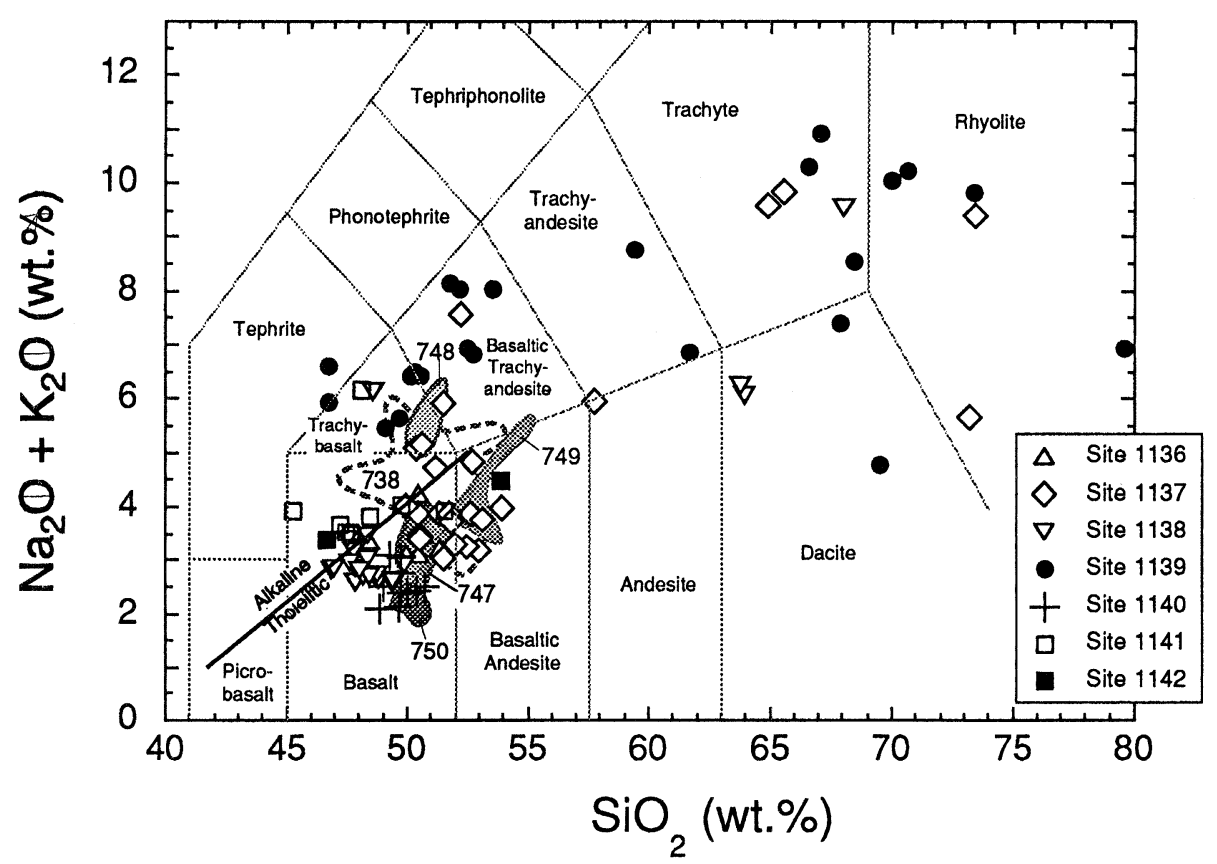

Fig. 4. Total alkalis $\left(\mathrm{Na}_{2} \mathrm{O}+\mathrm{K}_{2} \mathrm{O}\right)$ versus $\mathrm{SiO}_{2}$ classification plot for igneous rocks recovered by drilling on the Kerguelen Plateau and Broken Ridge. Although in detail this plot is affected by post-magmatic mobility of alkalis, the principal aspects of the data reflect magmatic characteristics. Important features are: (a) the dominance of basalt with subordinate trachyte, rhyolite and dacite at Sites 1137, 1138 and 1139; and (b) lavas at some sites are dominantly tholeiitic basalt (Sites 750 and 1140) whereas the low $\mathrm{SiO}_{2}$ lavas at Site 1139 are alkalic (trachybasalt and basaltic trachyandesite). Data sources are in EPSL Online Background Data Set (see footnote 1).

uppermost tholeiitic basalts forming the Kerguelen Plateau, however, do not have compositions expected of primary melts derived from partial melting of peridotite; for example, basement basalts from Leg 183 drillsites range in $\mathrm{MgO}$ content from 2.8 to $8.1 \% \mathrm{MgO}$ and $\mathrm{Ni}$ contents are $<100$ ppm at five of the seven sites. Their evolved compositions imply significant cooling, partial crystallization and segregation of mafic phases (olivine and pyroxene) from mantle-derived primary magmas as they ascended through the lithosphere. This inference is consistent with the thick, high seismic velocity, lower crust that is characteristic of oceanic plateaus and interpreted as olivine and pyroxene-rich rocks segregated from plume-derived primary magmas [37]. For example, seismic velocities increase with depth from 6.6 to $7.4 \mathrm{~km} / \mathrm{s}$ in the $\sim 17 \mathrm{~km}$ thick lower crust of the CKP $[18,19]$. Moreover, xenoliths of such cumulate rocks from the lower crust/upper mantle occur in Kerguelen Archipelago lavas [38].
In contrast to lavas from other drillsites, the basement lavas at Skiff Bank (Site 1139 in Fig. 1) comprise an alkaline lava series ranging from trachybasalt to trachyte and rhyolite (Fig. 4). Similar alkaline lavas have erupted in the Kerguelen Archipelago in early Miocene and Pliocene/ Pleistocene time [39]. Skiff Bank, which crests $<500 \mathrm{~m}$ below sea level, may have been a somewhat older island analogous to the Kerguelen Archipelago, $350 \mathrm{~km}$ to the east-northeast (Fig. 1).

An unexpected result of the recent Leg 183 drilling was the discovery that highly evolved, felsic magma was erupted explosively during the final stages of volcanism over extensive regions of the Kerguelen Plateau. Previous drilling at four ODP sites found no evidence for explosive felsic magmatism, but at three Leg 183 drillsites (1137, 1138 and 1139), we recovered both pyroclastic flow deposits and lavas of trachyte, dacite and quartz-bearing rhyolite (Figs. 3 and 4). At Site 1137 on Elan Bank, a 15 m thick sanidine-rich 
vitric tuff is intercalated between basaltic lava flows. Well preserved bubble-wall glass shards in part of the tuff together with abundant broken crystals indicate an explosive volcanic eruption. Higher in the stratigraphic sequence at Elan Bank, a fluvial conglomerate contains clasts of rhyolitic and trachytic lavas. At Site 1138 on the CKP, we recovered a $20 \mathrm{~m}$ thick volcaniclastic succession containing six trachytic pumice lithic breccias that were deposited by pyroclastic flows. This volcaniclastic sequence also includes highly altered ash fall deposits that contain accretionary lapilli. Above this sequence, we recovered rounded cobbles of flow-banded dacite. At Site 1139 on Skiff Bank, which forms part of the NKP, the uppermost basement contains a variety of felsic volcanic and volcaniclastic rocks. In contrast to the CKP and Elan Bank sites, biostratigraphic ages of sediments directly overlying this basement suggest that this felsic volcanism is Cenozoic in age. The Skiff Bank section includes densely welded pyroclastic flow deposits of quartz-bearing rhyolite, in addition to lava flows and reworked cobbles of volcanic rock ranging from sanidine-rich trachyte to rhyolite.

Evolved magmas (e.g. trachyte, phonolite, rhyolite) are erupted during plume-related volcanism at oceanic islands and in some continental flood basalt provinces. Typically these eruptions occur near the end of voluminous, basaltic magmatism. Two alternative modes of formation for highly evolved magmas are partial melting of lower crustal rocks or as residual magmas created when the supply of mantle-derived basaltic magma wanes, leading to formation of crustal level magma chambers in which highly evolved magma forms through crystal fractionation of basalt $( \pm$ wallrock assimilation). Preliminary isotopic data for felsic clasts in the conglomerate at Site 1137 indicate that the felsic magmas formed by combined fractional crystallization and assimilation of a component with relatively high ${ }^{87} \mathrm{Sr} /{ }^{86} \mathrm{Sr}$ [40].

\section{Environmental effects}

The eruption of enormous volumes of basaltic magma during formation of the Kerguelen Pla- teau and Broken Ridge probably had significant environmental consequences due to release of volatiles such as $\mathrm{CO}_{2}, \mathrm{~S}, \mathrm{Cl}$ and $\mathrm{F}$. A key factor in the magnitude of volatile release is whether the eruptions were subaerial or submarine; hydrostatic pressure inhibits vesiculation and degassing of relatively soluble volatile components $\left(\mathrm{H}_{2} \mathrm{O}, \mathrm{S}\right.$, $\mathrm{Cl}, \mathrm{F}$ ) during deep water submarine eruptions, although low solubility components $\left(\mathrm{CO}_{2}\right.$, noble gases) are mostly degassed even at abyssal depths. Results of Leg 183 drilling complement earlier results from Legs 119 and 120 in demonstrating that voluminous subaerial basaltic eruptions occurred during the final constructional stages of the plateau.

Another important factor that would have increased the environmental consequences of Kerguelen Plateau and Broken Ridge volcanism is the high latitude at which the plateau formed (Fig. 2). In most basaltic eruptions, released volatiles remain in the troposphere. However, at high latitudes, the tropopause is relatively low, allowing large mass flux, basaltic fissure eruption plumes to transport $\mathrm{SO}_{2}$ and other volatiles into the stratosphere $[41,42]$. Sulfuric acid aerosol particles that form in the stratosphere after such eruptions have a longer residence time and greater global dispersal than if the $\mathrm{SO}_{2}$ remains in the troposphere; therefore, they have greater effects on climate and atmospheric chemistry. The large volume and long duration of subaerial basaltic volcanism on the Kerguelen Plateau and Broken Ridge, combined with the high latitude of most of the plateau, would all have contributed to potential global environmental effects.

Highly explosive felsic eruptions, such as those that produced the pyroclastic deposits on Elan Bank, Skiff Bank and the CKP, can also inject both particulate material and volatiles $\left(\mathrm{SO}_{2}\right.$, $\mathrm{CO}_{2}$ ) directly into the stratosphere [43]. The previously unrecognized, significant volume of explosive felsic volcanism that occurred when the Kerguelen Plateau and Broken Ridge were subaerial would have further contributed to the effects of this plume volcanism on global climate and environment. The total volume of felsic volcanic rocks is still poorly constrained, but our results indicate that they account for a significant fraction of the 
volcanic deposits erupted during the final stages of magmatism at several locations on the Kerguelen Plateau.

\section{Magma sources for the Kerguelen Plateau and Broken Ridge}

Tholeiitic basalts erupted at spreading ridge axes, commonly known as mid-ocean ridge basalts (MORB), have relatively low abundances of highly incompatible elements (i.e. their abundance ratios of highly to moderately incompatible elements are less than those of primitive mantle). Relative to other basalts, MORB also have a relatively low ${ }^{87} \mathrm{Sr} /{ }^{86} \mathrm{Sr}$ and high ${ }^{143} \mathrm{Nd} /{ }^{144} \mathrm{Nd}$ (Fig. 5 ), thereby indicating that relative depletion of highly incompatible elements is a long-term characteristic of their mantle source. In contrast, the tholeiitic basalts forming the Kerguelen Plateau and Broken Ridge have abundance ratios of highly to moderately incompatible elements similar to or greater than those of primitive mantle [44-46], and ${ }^{87} \mathrm{Sr} /{ }^{86} \mathrm{Sr}$ and ${ }^{143} \mathrm{Nd} /{ }^{144} \mathrm{Nd}$ which range to higher and lower ratios, respectively (Fig. 5). These isotopic data require that the sources of oceanic plateaus and MORB had long-term differences in the parent/daughter abundance ratios, $\mathrm{Rb} / \mathrm{Sr}$ and $\mathrm{Sm} / \mathrm{Nd}$.

Although the Kerguelen Plateau and Broken Ridge basement are dominantly tholeiitic basalt, an important result is that basalt from each sampling site is geochemically distinct. These differences include major and trace element abundances (Figs. 4 and 6) and radiogenic isotopic ratios (Fig. 5). Some geochemical differences were caused by post-melting processes, but many require geochemically heterogeneous sources. Likely, mantle sources for the tholeiitic basalt magmas that constructed the Kerguelen Plateau and Broken Ridge are the Kerguelen plume and upper mantle asthenosphere; e.g. entrainment of the asthenosphere by the plume or mixing of plume and asthenosphere-derived magmas when the plume was close to a spreading ridge axis. For example, during growth of the Ninetyeast Ridge and the northern NKP, the Kerguelen plume was close to a spreading center (Fig. 2). The $\mathrm{Sr}$ and $\mathrm{Nd}$ isotopic trend defined by the tholeiitic basalts forming the Ninetyeast Ridge is consistent with mixing between plume and asthenosphere; for example, basalts from Ninetyeast Ridge Site 756 overlap with the field for SEIRs (a subgroup of basalts from SKP Site 749 also overlaps with SEIR MORB) whereas basalts from Ninetyeast Ridge Site 216 overlap with the field proposed for the Kerguelen plume (Fig. 5).

The role of continental lithosphere in forming the Kerguelen Plateau and the Kerguelen Archipelago has been debated [46-49], but there is no compelling evidence for a continental component in the $<38$ Ma lavas forming the Kerguelen Archipelago [50] or the $\sim 38-82 \mathrm{Ma}$ lavas forming the Ninetyeast Ridge [51-53]. In contrast, isotopic evidence suggests a continental component in the recent Big Ben volcanic series of Heard Island on the CKP [54], and in some mantle xenoliths found in Kerguelen Archipelago lavas [55,56]. Also, isotopic data for Cretaceous basalts from some sites on Kerguelen Plateau and Broken Ridge provide evidence for a continental component. For example, $\mathrm{Sr}-\mathrm{Nd}$ isotopic fields defined by basalt from

Fig. 5. Upper panel: ${ }^{143} \mathrm{Nd} /{ }^{144} \mathrm{Nd}$ versus ${ }^{87} \mathrm{Sr} /{ }^{86} \mathrm{Sr}$ showing data points for basalts recovered from the Kerguelen Plateau and Broken Ridge. The Broken Ridge samples are measured data corrected to an eruption age of $88 \mathrm{Ma}$, the dredged Kerguelen Plateau samples are measured data corrected to an eruption age of $115 \mathrm{Ma}$. The effects of age correction are shown by the two fields (measured and age-corrected) for ODP Site 738 on the SKP. Data for other ODP sites are not age-corrected because parent/daughter abundance ratios are not available. Shown for comparison are fields for SEIR MORB (distant from the St. Paul-Amsterdam platform), St. Paul and Heard Islands (Heard data indicated by trajectory of solid line), the Ninetyeast Ridge (shaded fields labelled Ninetyeast Ridge and Ninetyeast Ridge DSDP Site 216, and the entire Kerguelen Archipelago. Most samples from the Kerguelen Archipelago plot in the subfield labelled 'Kerguelen Plume?' Lower panel: ${ }^{208} \mathrm{~Pb} /{ }^{204} \mathrm{~Pb}$ versus ${ }^{206} \mathrm{~Pb} /{ }^{204} \mathrm{~Pb}$ showing measured data points for basalts recovered from the Kerguelen Plateau and Broken Ridge. Shown for comparison are measured fields for SEIR MORB (distant from the St. Paul-Amsterdam platform), lavas from St. Paul and Amsterdam Islands and initial ratios for lavas from the Kerguelen Archipelago and the Ninetyeast Ridge. Data sources for both panels are in EPSL Online Background Data Set (see footnote 1). 
Site $738\left(\sim 63^{\circ} \mathrm{S}\right.$ on the SKP) and Dredge 8 (eastern Broken Ridge) are well beyond those of oceanic island basalt (Fig. 5). High ${ }^{87} \mathrm{Sr} /{ }^{86} \mathrm{Sr},{ }^{207} \mathrm{~Pb} /$ ${ }^{204} \mathrm{~Pb},{ }^{208} \mathrm{~Pb} /{ }^{204} \mathrm{~Pb}$ and low ${ }^{143} \mathrm{Nd} /{ }^{144} \mathrm{Nd},{ }^{206} \mathrm{~Pb} /$ ${ }^{204} \mathrm{~Pb}$ (Fig. 5) coupled with relative depletion in abundances of $\mathrm{Nb}$ and $\mathrm{Ta}$ are compelling evidence that Site 738 basalts contain a continental component [46]. Similar geochemical characteristics occur in the crustally contaminated Bunbury Basalt of western Australia, a 123-130 Ma continental basaltic province that has been attributed to the Kerguelen plume [57]. Although not as striking, relatively high ${ }^{87} \mathrm{Sr} /{ }^{86} \mathrm{Sr}$ and low ${ }^{143} \mathrm{Nd} /$

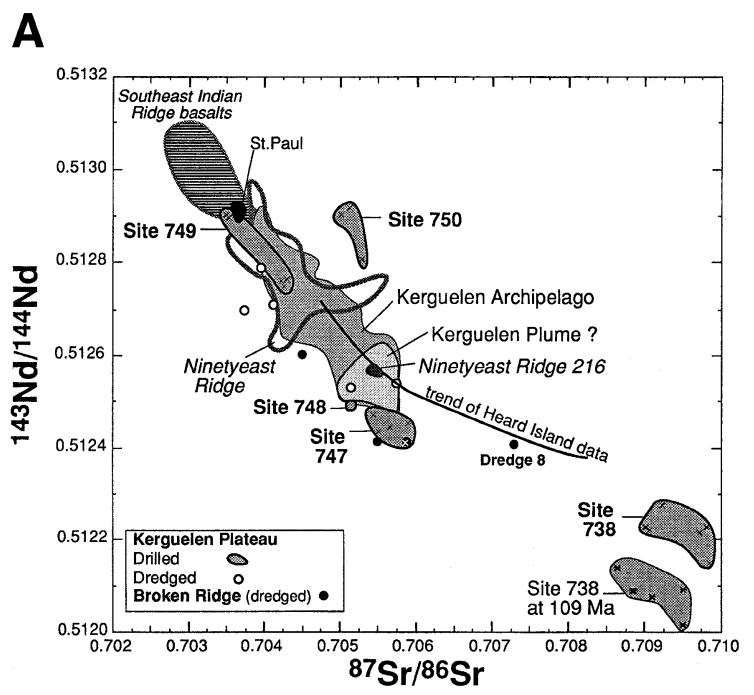

B

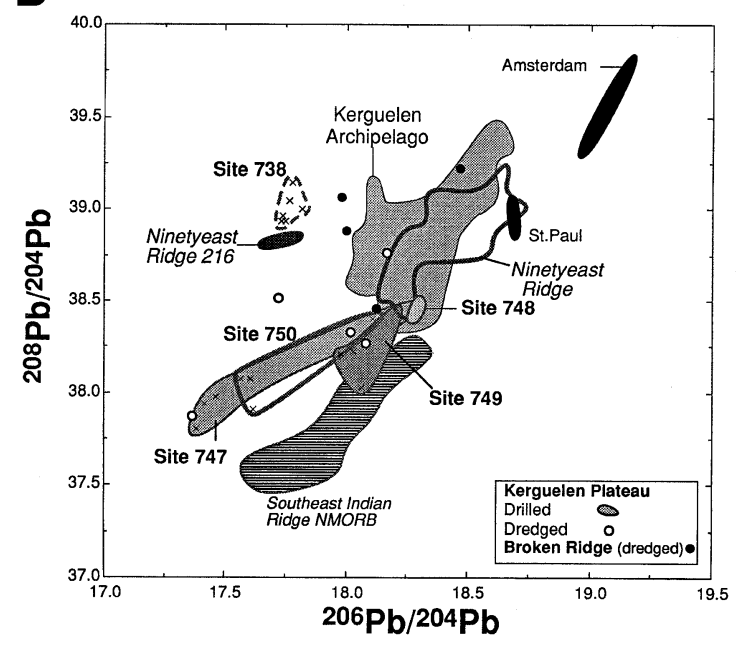

${ }^{144} \mathrm{Nd}$ and ${ }^{206} \mathrm{~Pb} /{ }^{204} \mathrm{~Pb}$ coupled with relatively low $\mathrm{Nb}$ abundances [44] also characterize basalt from CKP Site 747 (Fig. 5). Lead isotopic ratios are especially sensitive for identifying a continental crust component because typical $\mathrm{Pb}$ contents in continental crust exceed those of basalt by a factor of two or more. Relative to the $\mathrm{Pb}$ isotopic fields for basalts of the Kerguelen Archipelago and Ninetyeast Ridge, Site 747 and most other Kerguelen Plateau and Broken Ridge basalts are offset to low ${ }^{206} \mathrm{~Pb} /{ }^{204} \mathrm{~Pb}$ at a given ${ }^{208} \mathrm{~Pb} /{ }^{204} \mathrm{~Pb}$ (Fig. 5). This offset to low ${ }^{206} \mathrm{~Pb} /{ }^{204} \mathrm{~Pb}$ requires a long-term low $\mathrm{U} / \mathrm{Pb}$ ratio; low $\mathrm{U} / \mathrm{Pb}$ ratios are characteristic of lower continental crust and pelagic clays $[58,59]$. Finally, geochemical evidence for a continental component in basalts forming the Kerguelen Plateau and Broken Ridge is consistent with crustal velocity structure determined by wide-angle seismic data that suggest a stretched continental fragment in the SKP at $\sim 58^{\circ} \mathrm{S}[17,18]$. Therefore, accumulating evidence suggests that the effects of continental material are widespread in the Kerguelen Plateau and Broken Ridge.

A major objective of ODP Leg 183 was to sample the Kerguelen Plateau and Broken Ridge in diverse areas to constrain the spatial and temporal role of continental components. Only preliminary isotopic data are available for the recently acquired (December 1998-February 1999) Leg 183 basalts [40]. However, shipboard-obtained trace element abundances are useful in evaluating the relative roles of plume, asthenosphere and continental components. A $\mathrm{Nb} / \mathrm{Y}$ versus $\mathrm{Zr} / \mathrm{Y}$ plot has been used to distinguish between lavas derived from the Icelandic plume and North Atlantic MORB [60]. Lavas, varying from $\sim 82 \mathrm{Ma}$ to Pliocene/Pleistocene in age, associated with the Kerguelen plume define a $\mathrm{Nb} / \mathrm{Y}-\mathrm{Zr} / \mathrm{Y}$ field overlapping the lower boundary for the Icelandic plume (Fig. 6); we infer that the Kerguelen plume lies on this boundary. Not surprisingly, the Kerguelen and Icelandic plumes are geochemically distinct. Basement basalts from Broken Ridge and several locations on the Kerguelen Plateau also lie along this trend (namely, Sites 747, 1136, 1138 and 1140). Two Kerguelen Plateau sites are within the Icelandic field (Sites 749 and 
750), and two others (Sites 738 and 1137), like MORB, lie below the plume field. However, basalts from Site 738 do not have MORB isotopic characteristics (Fig. 6). Because continental crustal rocks also plot below the plume field, plumerelated basalts contaminated by continental crust define a trend very similar to that of basalts from Site 738 and 1137 (Fig. 6). We infer that these basalts are plume-derived basalts that were contaminated by continental crust.

Intercalated within the $\sim 150 \mathrm{~m}$ of dominantly basaltic basement at Site 1137 (Elan Bank) is a $\sim 26 \mathrm{~m}$ section of fluvial conglomerate. This conglomerate contains diverse clasts ranging from basalt to porphyritic trachyte and flow-banded rhyolite to granitoid and garnet-biotite gneiss (Fig. 7). These clasts provide a sampling of the subaerial Elan Bank during Late Cretaceous time. The source for clasts of garnet-biotite gneiss is unequivocally continental crust. Ongoing age determinations and isotopic studies of these clasts and basement basalt by the shipboard scientific party will test the hypothesis that Site 1137 basalts were contaminated by continental crust similar to that exposed on Elan Bank [40,61]. A closer look at the metamorphic and granitic rocks, originally interpreted as ice-rafted debris, dredged from an exposed faulted basement block in the Labuan Basin [22], is clearly warranted.

\section{A mechanism for introduction of continental lithosphere into an oceanic environment}

Continental material, whether derived from continental crust or subcrustal continental lithosphere, is occasionally incorporated into oceanic lithosphere. Examples range from microcontinents such as Seychelles and Jan Mayen with normal or reduced continental crustal thicknesses to fragments of continental derived rocks to geochemical signatures in oceanic basalts that have been interpreted to represent the influence of deeply recycled continental lithosphere (e.g. [6265]). As described above, evidence for continental components in the Kerguelen Plateau and Broken Ridge encompasses a range of petrologic, geochemical and geophysical signatures that may re-
Fig. 6. $\mathrm{Nb} / \mathrm{Y}$ versus $\mathrm{Zr} / \mathrm{Y}$. This discrimination plot [60] distinguishes between basalts derived from the Icelandic plume (data lying within the diagonal lines labelled 'Icelandic Plume') and MORB derived from the North Atlantic asthenosphere (data lying below the lower diagonal line). Fitton et al. [60] showed that basalts derived from a common peridotite source by variable extents of melting define a trend parallel to these lines. The upper panel shows $82 \mathrm{Ma}$ to recent lavas associated with the Kerguelen plume. These lavas, tholeiitic basalts from the Ninetyeast Ridge and transitional to alkalic basalts from the Kerguelen Archipelago, define a trend that overlaps the lower boundary line. A representative field for SEIR MORB is shown for comparison. The lower panel shows results for basement basalts from Kerguelen Plateau and Broken Ridge. The most straightforward interpretation of the data for basalts from the Ninetyeast Ridge, Kerguelen Archipelago, Kerguelen Plateau and Broken Ridge is that the Kerguelen plume lies along the lower boundary line for the Icelandic plume. This result is not surprising since mantle heterogeneity is largely expressed by a vertical trend, variable $\mathrm{Nb} / \mathrm{Y}$, in this figure or in other words all plumes do not have the same $\mathrm{Nb} / \mathrm{Y}$ ratio. Note that an offset to lower $\mathrm{Nb} / \mathrm{Y}$ at a given $\mathrm{Zr} / \mathrm{Y}$ is characteristic of MORB and continental crust. A principally MORB source for basalts derived from the Kerguelen plume is unlikely given their $\mathrm{Sr}$ and $\mathrm{Nd}$ isotopic ratios (Fig. 5). Therefore, we interpret that data for basalts from Sites 738 and 1137 lie on the MORB side of the dividing line because they are plume-derived basalts that have been contaminated by continental crust. For reference, points are shown for primitive mantle (PM), average MORB, average oceanic island alkalic basalt (OIB), upper and lower continental crustal averages (UCC and LCC, respectively). Data sources for both panels are in EPSL Online Background Data Set (see footnote 1).

flect more than one process. However, the simplest mechanism for incorporating continental material into the Kerguelen Plateau is a ridge jump post-dating breakup and initial seafloor spreading between India and Antarctica. One or more ridge jumps to the north would have transferred continental parts of the Indian plate to oceanic portions of the Antarctic plate, accounting for features like Elan Bank and the portion of the SKP characterized by continental crustal velocities. Published plate motion models (Fig. 2) do not show any ridge jumps because the oceanic crust between Antarctic and Kerguelen Plateau formed during the long Cretaceous Normal Superchron, and is therefore not datable using the usual technique of marine magnetic anomaly identification. Nevertheless, the unambiguously 


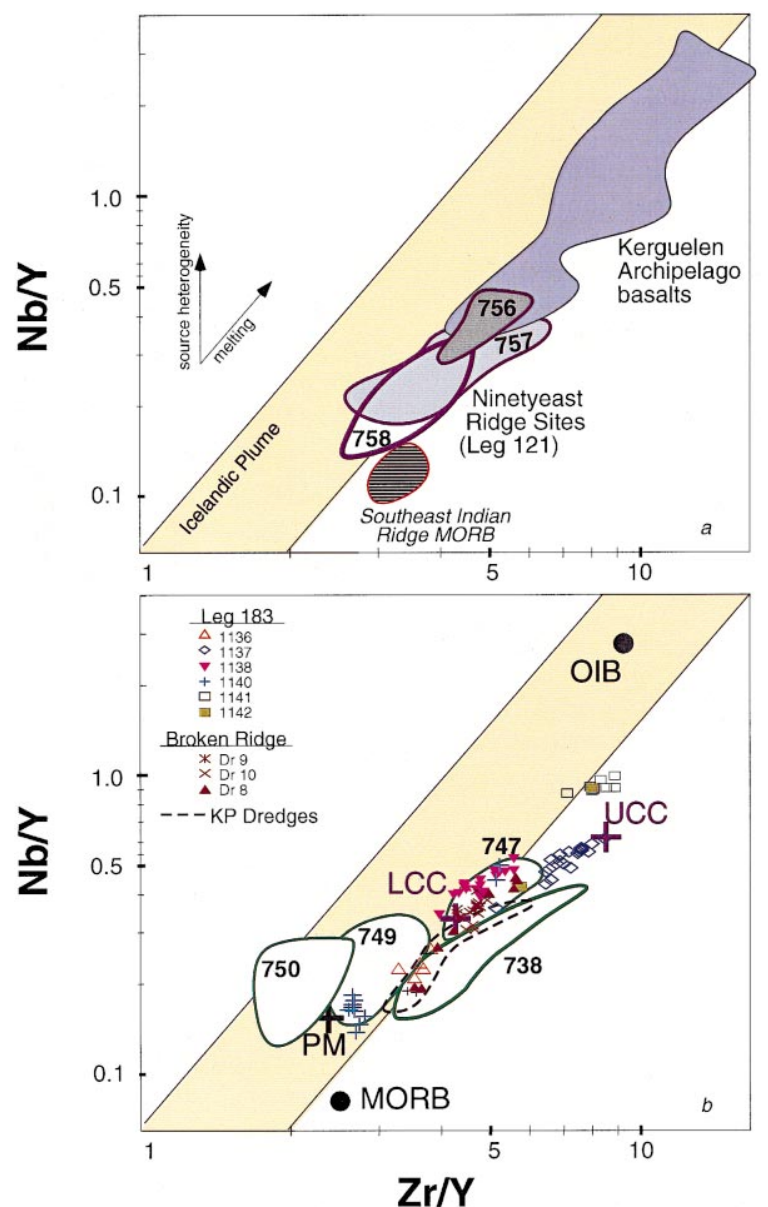

continental garnet-biotite gneiss recovered from Site 1137 on Elan Bank strongly suggests that at least one northward ridge jump transferred a continental fragment, Elan Bank, from the Indian to the Antarctic plate. The ages of zircons in this gneiss will test this hypothesis.

\section{Conclusions}

Recovery of volcanic rocks and interbedded and overlying sediments on ODP Legs 119, 120 and 183 indicate that:

(a) Much of the SKP and perhaps Elan Bank formed at $\sim 110 \mathrm{Ma}$, but younger ages, $\sim 85 \mathrm{Ma}$, have been reported for the CKP and Broken Ridge $[8,27,28]$. In progress dating of lavas from
Leg 183 Site 1138 will more firmly establish the age of the CKP. Subsequent to formation of the SKP, Elan Bank, CKP and Broken Ridge, plate motions over the Kerguelen plume resulted in formation of Ninetyeast Ridge $(\sim 82-38 \mathrm{Ma})$ and the NKP ( $\leq 35 \mathrm{Ma})$. Before Leg 183, the submarine igneous basement of Elan Bank and the NKP was unsampled.

(b) The growth rate of the Kerguelen Plateau and Broken Ridge at five of seven new drillsites was sufficient to form subaerial landmasses. This was most spectacularly revealed at Site 1138 on the CKP by wood fragments in a dark brown
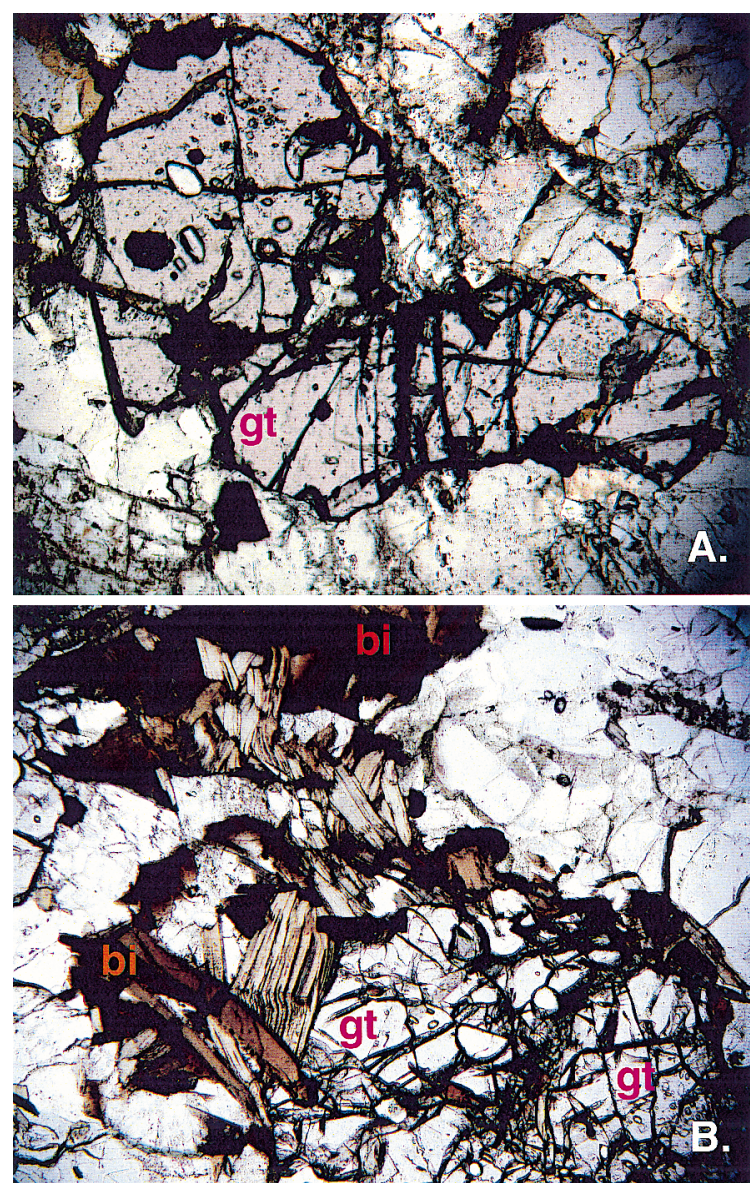

Fig. 7. Photomicrograph of garnet gneiss clasts in basement rocks at Site 1137 (Elan Bank). A: Poikiloblastic (gt) in a conglomerate clast. Field of view is $1.4 \mathrm{~mm}$, plane-polarized light. B: Porphyroblastic garnet (gt) and biotite (bi) in a clast contained in a crystal-vitric tuff. Field of view is 2.75 $\mathrm{mm}$, plane-polarized light. 
sediment overlying the subaerially erupted lava flows, a result consistent with the charcoal and wood fragments in sediments overlying igneous rocks at ODP Site 750 in the SKP [66].

(c) Tholeiitic basalt is the dominant rock forming the Cretaceous Kerguelen Plateau/Broken Ridge LIP, the Ninetyeast Ridge and the NKP; the volume and age progression and geochemical characteristics of these basalts are consistent with derivation from a long-lived Kerguelen plume.

(d) The terminal stage of volcanism forming the LIP included explosive eruptions of volatile-rich felsic magmas, which adds a new dimension to the potential of oceanic plateau magmatism for instigating global environmental change.

(e) At Site 1137 on Elan Bank, 26 m of fluvial conglomerate is intercalated with basaltic flows; most notable are clasts of garnet-biotite gneiss, a continental crustal rock. This is the first unequivocal evidence of continental crust from the Kerguelen Plateau and Broken Ridge. Previous geochemical studies of basalt from the SKP and eastern Broken Ridge identified a component derived from continental crust $[44,46]$, but the mechanism for incorporation of a continental component into the oceanic plateau was unconstrained. Possible processes range from recycling of continental material into a deep mantle plume to contamination of mantle-derived basaltic magma by fragments of continental crust isolated in the embryonic Indian Ocean crust by spreading center jumps during early seafloor spreading between Antarctica and India. The latter process is consistent with the finding of continental rock on Elan Bank.

\section{Acknowledgements}

We thank the master (A. Ribbens), drilling superintendent (S. Pederson), operations manager (M. Storms) and crew of the JOIDES Resolution for their dedication and efforts during ODP Leg 183. We are also grateful to JOIDES, JOI, and ODP for making Legs 183, 120 and 119 happen. The Australian Geological Survey Organization (P. Symonds) and Ecole et Observatoire des Sciences de la Terre of the Université Louis Pasteur
(Strasbourg 1; R. Schlich) generously provided all of the multichannel seismic site survey data for Legs 183, 120 and 119. Finally, G. Fitton and A. Saunders are thanked for their useful review comments. This is the University of Texas at Austin Institute for Geophysics contribution \#1488.[CL]

\section{References}

[1] R.L. Larson, Geological consquences of superplumes, Geology 19 (1991) 963-966.

[2] M. Coffin, O. Eldholm, Large igneous provinces: crustal structure, dimensions and external consequences, Rev. Geophys. 32 (1994) 1-36.

[3] M. Stein, A.W. Hofmann, Mantle plumes and episodic crustal growth, Nature 373 (1994) 63-68.

[4] W.J. Morgan, Hotspot tracks and the opening of the Atlantic and Indian Oceans, in: C. Emiliani (Ed.), The Sea, Vol. 7, Wiley, New York, pp. 443-487.

[5] R.A. Duncan and M. Storey, The life cycle of Indian Ocean hotspots, in: R.A. Duncan, D.K. Rea, R.B. Kidd, U. von Rad and J.K. Weissel (Eds.), Synthesis of Results from Scientific Drilling in the Indian Ocean, Geophys. Monogr. 70, Am. Geophys. Union, 1992, pp. 91103.

[6] D. Weis, W.M. White, F.A. Frey, R.A. Duncan, J. Dehn, M. Fisk, J. Ludden, A. Saunders and M. Storey, The influence of mantle plumes in generation of Indian oceanic crust, in: R.A. Duncan, D.K. Rea, R.B. Kidd, U. von Rad and J.K. Weissel (Eds.), Synthesis of Results from Scientific Drilling in the Indian Ocean, Geophys. Monogr. 70, Am. Geophys. Union, 1992, pp. 57-89.

[7] J.J. Mahoney, J.D. McDougall, G.W. Lugmair, K. Gopalan, Kerguelen hot spot source for the Rajmahal traps and Ninetyeast Ridge?, Nature 303 (1983) 385-389.

[8] R.A. Duncan, Age distribution of volcanism along aseismic ridges in the eastern Indian Ocean, in: J. Weissel, J. Peirce, E. Taylor, J. Alt, et al., Proc. Ocean Drill. Prog., Scientific Results 121, Ocean Drill. Prog., College Station, TX, 1991, pp. 507-517.

[9] M.F. Coffin, M. Munschy, J.B. Colwell, R. Schlich, H.L. Davies, Z.G. Li, Seismic stratigraphy of the Raggatt Basin, southern Kerguelen Plateau: tectonic and paleoceanographic implications, Geol. Soc. Am. Bull. 102 (1990) 563-579.

[10] M. Schaming, Y. Rotstein, Basement reflectors in the Kerguelen Plateau, south Indian Ocean: Implications for the structure and early history of the plateau, Geol. Soc. Am. Bull. 102 (1990) 580-592.

[11] M.F. Coffin, H.L. Davies, W.F. Haxby, Structure of the Kerguelen Plateau province from SEASAT altimetry and seismic reflection data, Nature 324 (1986) 134-136.

[12] B. Fritsch, R. Schlich, M. Munschy, F. Fezga and M.F. 
Coffin, Evolution of the southern Kerguelen Platau deduced from seismic stratigraphic studies and drilling at sites 748 and 750, in: S.W. Wise Jr., R. Schlich, et al., Proc. Ocean Drill. Prog., Scientific Results 120, Ocean Drill. Prog., College Station, TX, 1992, pp. 895-906.

[13] Y. Rotstein, R. Schlich, M. Munschy, M.F. Coffin, Structure and tectonic history of the southern Kerguelen Plateau (Indian Ocean) deduced from seismic reflection data, Tectonics 11 (1992) 1332-1347.

[14] J.-Y. Royer and M.F. Coffin, Jurassic to Eocene plate tectonic reconstructions in the Kerguelen Plateau region, in: W.S. Wise, R. Schlich, et al., Proc. Ocean Drill. Prog., Scientific Results 120, College Station, TX, 1992, pp. 917928.

[15] M.P. Angouluant-Coulon, R. Schlich, Mise en evidence d'une nouvelle direction tectonique sur le plateau de Kerguelen, C.R. Acad. Sci. Paris Ser. 2319 (1994) 929935.

[16] L. Könnecke, M.F. Coffin, Early development of the southern Kerguelen Plateau (Indian Ocean) from ocean bottom seismograph and multichannel seismic reflection data, J. Geophys. Res. 103 (1998) 24085-24108.

[17] S. Operto, P. Charvis, Kerguelen Plateau: a volcanic passive margin fragment?, Geology 23 (1995) 137-140.

[18] S. Operto, P. Charvis, Deep structure of the southern Kerguelen Plateau (southern Indian Ocean) from ocean bottom seismometer wide-angle seismic data, J. Geophys. Res. 101 (1996) 25077-25103.

[19] P. Charvis, M. Recq, S. Operto, D. Brefort, Deep structure of the northern Kerguelen Plateau and hotspot-related activity, Geophys. J. Int. 122 (1995) 899-924.

[20] J.C. Mutter, S.C. Cande, The early opening between Broken Ridge and Kerguelen Plateau, Earth Planet. Sci. Lett. 65 (1983) 369-376.

[21] J.K. Weissel, G.D. Karner, Flexural uplift of rift flanks due to mechanical unloading of the lithosphere during extension, J. Geophys. Res. 94 (1989) 13919-13950.

[22] T. Montigny, A.M. Karpoff and C. Hofmann, Résultats d'un dragage par $55^{\circ} 18^{\prime} \mathrm{S}-83^{\circ} 04^{\prime} \mathrm{E}$ dans le Bassin de Labuan (campagne MD67), océan Indien méridional: implications géodynamique, (abs.), Société Géologique de France, Journées Spécialisées, 1993, p. 83.

[23] M. Recq, D. Brefort, J. Malod, J.-L. Veinante, The Kerguelen Isles (Southern Indian Ocean) New results on deep structure from refraction profiles, Tectonophysics 182 (1990) 227-248.

[24] M. Recq, I. LeRoy, P. Charvis, J. Goslin, D. Brefort, Structure profonde du mont Ross d'après la réfraction sismique (les Kerguelen océan Indien austral), Can. J. Earth Sci. 31 (1994) 1806-1821.

[25] L. Leclaire, Y. Bassias, M. Denis-Clochiatti, H.L. Davies, I. Gautier, B. Gensous, P.-J. Giannesini, P. Patriat, J. Ségoufin, M. Tesson, J. Wannesson, Lower Cretaceous basalt and sediments from the Kerguelen Plateau, GeoMar. Lett. 7 (1987) 169-176.

[26] H. Whitechurch, R. Montigny, J. Sevigny, M. Storey and V. Salters, $\mathrm{K}-\mathrm{Ar}$ and ${ }^{40} \mathrm{Ar}-{ }^{39} \mathrm{Ar}$ ages of central Kerguelen
Plateau basalts, in: Proc. Ocean Drill. Prog., Scientific Results 120, W.S. Wise and R. Schlich, et al., Ocean Drill. Prog., College Station, TX, 1992, pp. 71-77.

[27] M.S. Pringle, M. Storey, J. Wigbrans, ${ }^{40} \mathrm{Ar} /{ }^{39} \mathrm{Ar}$ geochronology of mid-Cretaceous Indian ocean basalts: constraints on the origin of large flood basalt provinces, EOS Trans. Am. Geophys. Union 75 (1994) W728.

[28] M. Storey, M.S. Pringle, M.F. Coffin, J. Wijbrans, Geochemistry and geochemistry of Kerguelen Plateau basalts: results form ODP Legs 119 and 120, EOS Trans. Am. Geophys. Union 77 (1977) 123.

[29] F. Fröhlich, E. Wicquart, Upper Cretaceous and Paleogene sediments from the northern Kerguelen Plateau, Geo-Mar. Lett. 9 (1989) 127-133.

[30] A. Giret and J. Lameyre, A study of Kerguelen plutonism: petrology, geochronology and geological implications, in: R.L. Oliver, P.R. James and J.B. Jago (Eds.), Antarctic Earth Science, Australian Academy of Sciences, Canberra, 1983, pp. 646-651.

[31] D. Weis, F.A. Frey, A. Giret, J.M. Cantagrel, Geochemical characteristics of the youngest volcano (Mount Ross) in the Kerguelen Archipelago: Inferences for magma flux, lithosphere assimilation and composition of the Kerguelen Plume, J. Petrol. 39 (1998) 973-994.

[32] K. Nicolaysen, F.A. Frey, K.V. Hodges, D. Weis and A. Giret, ${ }^{40} \mathrm{Ar} /{ }^{39} \mathrm{Ar}$ Geochronology of flood basalts from the Kerguelen Archipelago, southern Indian Ocean: Implications for Cenozoic eruption rates of the Kerguelen Plume, Earth Planet. Sci. Lett. (in press).

[33] I. Clarke, I. McDougall and D. Whitford, Volcanic evolution of Heard and McDonald Islands, southern Indian Ocean, in: R.L. Oliver, P.R. James and J.B. Jago (Eds.), Antarctic Earth Science, Australian Academy of Sciences, Canberra, 1983, pp. 631-635.

[34] P.G. Quilty, S. Shafik, A. McMinn, H. Brady and I. Clarke, Microfossil evidence for the age and environment of deposition of sediments of Heard and McDonald Islands, in: R.L. Oliver, P.R. James and J.B. Jago (Eds.), Antarctic Earth Science, Australian Academy of Sciences, Canberra, 1983, pp. 636-639.

[35] D. Weis, D. Damasceno, J.S. Scoates, R. Schlich, M. Schaming, R. Montigny, F.A. Frey, Submarine alkali lavas (14-10 Ma) erupted between Heard Island and the Kerguelen Archipelago, EOS Trans. Am. Geophys. Union 79 (1998) F944.

[36] M.F. Coffin, Emplacement and subsidence of Indian Ocean Plateaus and submarine ridges, in: R.A. Duncan, D.K. Rea, R.B. Kidd, U. von Rad and J.K. Weissel (Eds.), Synthesis of Results From Scientific Drilling in the Indian Ocean, Geophys. Monogr. 70, Am. Geophys. Union, 1992, pp. 115-125.

[37] C. Farnetani, M.A. Richards, M.S. Ghiorso, Petrological models of magma evolution and deep crustal structure beneath hotspots and flood basalt provinces, Earth Planet. Sci. Lett. 143 (1996) 81-94.

[38] M. Gregoire, N. Mattieli, C. Nicollet, J.Y. Cottin, H. Leyrit, D. Weis, N. Shimizu, A. Giret, Oceanic mafic 
granulite xenoliths from the Kerguelen archipelago, Nature 367 (1994) 360-363.

[39] D. Weis, F.A. Frey, H. Leyrit, I. Gautier, Kerguelen Archipelago revisited: geochemical and isotopic study of the southeast province lavas, Earth Planet. Sci. Lett. 118 (1993) 101-119.

[40] D. Weis, J. Barling, D. Damasceno, F.A. Frey, K. Nicolaysen and the Leg 183 Shipboard Scientific Party, Evidence for a continental component at Elan Bank from Leg 183-Site 1137 on the Kerguelen Plateau, in: Ninth Annual V.M. Goldschmidt Conference, Lunar and Planetary Institute, Houston, TX, 1999, pp. 321-322.

[41] S. Self, L. Keszthelyi, T. Thordarson, The importance of Pahoehoe, Annu. Rev. Earth Planet. Sci. 26 (1998) 81110.

[42] R.B. Stothers, J.A. Wolff, S. Self, M.R. Rampino, Basaltic fissure eruptions, plume heights, and atmospheric aerosols, Geophys. Res. Lett. 13 (1986) 725-728.

[43] M.P. McCormick, L.W. Thomason, C.R. Trepte, Atmospheric effects of the Mt. Pinatubo eruption, Nature 373 (1995) 399-404.

[44] M. Storey, R.W. Kent, A.D. Saunders, V.J. Salters, J. Hergt, H. Whitechurch, J.H. Sevigny, M.F. Thirlwall, P. Leat, N.C. Ghose and M. Gifford, Lower Cretaceous volcanic rocks on continental margins and their relationship to the Kerguelen Plateau, in: S.W. Wise, R. Schlich, et al., Proc. Ocean Drill. Prog., Scientific Results 120, Ocean Drill. Prog., College Station, TX, 1992, pp. 33-53.

[45] K.W. Mehl, P.R. Bitschene, H.-U. Schmincke and J. Hertogen, Composition, alteration, and origin of the basement lavas and volcaniclastic rocks at Site 738 southern Kerguelen Plateau, in: J. Barron, B. Larsen, et al., Proc. Ocean Drill. Prog., Scientific Results 119, Ocean Drill, Prog, College Station, TX, 1991, pp. 299-322.

[46] J. Mahoney, W. Jones, F.A. Frey, V. Salters, D. Pyle, H. Davies, Geochemical characteristics of lavas from Broken Ridge, the Naturaliste Plateau and Southernmost Kerguelen Plateau: Early volcanism of the Kerguelen hotspot, Chem. Geol. 120 (1995) 315-345.

[47] N.D. Watkins, B.M. Gunn, J. Nougier, A.K. Baksi, Kerguelen: continental fragment or oceanic island?, Geol. Soc. Am. Bull. 85 (1974) 201-212.

[48] L. Dosso, V.R. Murthy, A Nd isotopic study of the Kerguelen Islands: inferences on enriched oceanic mantle sources, Earth Planet. Sci. Lett. 48 (1980) 268-276.

[49] D. Weis, F.A. Frey, H. Leyrit, I. Gautier, Kerguelen Archipelago revisited: geochemical and isotopic study of the southeast province lavas, Earth Planet. Sci. Lett. 118 (1993) 101-119.

[50] H.-J. Yang, F.A. Frey, D. Weis, A. Giret, D. Pyle, G. Michon, Petrogenesis of the flood basalts forming the northern Kerguelen Archipelago: Implications for the Kerguelen Plume, J. Petrol. 39 (4) (1998) 711-748.

[51] F.A. Frey, W.B. Jones, H. Davies and D. Weis, Geochemical and petrologic data for basalts from Sites 756, 757 and 758: Implications for the origin and evolution of Ninetyeast Ridge, in: J. Weissel, J. Peirce, J. Alt, et al.,
Proc. Ocean Drill. Prog., Scientific Results 121, Ocean Drill. Prog., College Station, TX, 1991, pp. 611-659.

[52] D. Weis and F.A. Frey, Isotope geochemistry of Ninetyeast Ridge basement basalts: $\mathrm{Sr}, \mathrm{Nd}$ and $\mathrm{Pb}$ evidence for the involvement of the Kerguelen hotspot, in: J. Weissel, J. Peirce, J. Alt, et al., Proc. Ocean Drill. Prog., Scientific Results 121, Ocean Drill. Prog., College Station, TX, 1991, pp. 591-610.

[53] F.A. Frey, D. Weis, Temporal evolution of the Kerguelen plume: geochemical evidence from $\sim 38$ to 82 Ma lavas forming the Ninetyeast Ridge, Contrib. Mineral. Petrol. 121 (1995) 12-28.

[54] J. Barling, S.L. Goldstein, I.A. Nicholls, Geochemistry of Heard Island (southern Indian Ocean): characterization of an enriched mantle component and implications for enrichment of the sub-Indian ocean mantle, J. Petrol. 35 (1994) 1017-1053.

[55] D. Hassler, N. Shimizu, Osmium isotopic evidence for ancient subcontinental mantle beneath the Kerguelen Islands, Southern Indian Ocean, Science 280 (1998) 418421.

[56] N. Mattielli, D. Weis, J.S. Scoates, N. Shimizu, J.-P. Mennessier, M. Gregoire, J.-Y. Cottin, A. Giret, Evolution of heterogeneous lithospheric mantle in a plume environment beneath the Kerguelen Archipelago, J. Petrol. 40 (1999) 1721-1744.

[57] F.A. Frey, N. McNaughton, D.R. Nelson, J.R. deLaeter, R. Duncan, Geochemistry characteristics of the Bunbury Basalts, western Australia: Interaction between the Kerguelen plume and Gondwana lithosphere, Earth Planet. Sci. Lett. 144 (1996) 163-183.

[58] R.L. Rudnick, D.M. Fountain, Nature and composition of the continental crust: a lower crustal perspective, Rev. Geophys. 33 (1995) 267-309.

[59] T. Plank, C.H. Langmuir, The chemical composition of subducting sediment and its consequences for the crust and mantle, Chem. Geol. 145 (1998) 325-394.

[60] J.G. Fitton, A.D. Saunders, M.J. Norry, B.S. Hardarson, R.N. Taylor, Thermal and chemical structure of the Iceland plume, Earth Planet. Sci. Lett. 153 (1997) 197-208.

[61] K.E. Nicolaysen, D. Weis, F.A. Frey, S.A. Bowring, M.F. Coffin and the Leg 183 Shipboard Scientific Party, Geochronological constraints on the source of continental rocks from the Kerguelen Plateau, ODP Site 1137 Elan Bank, in: Ninth Annual V.M. Goldschmidt Conference, Lunar and Planetary Institute, Houston, TX, 1999, pp. 208-209.

[62] J. Pilot, C.-D. Werner, F. Haubrich, N. Baumann, Palaeozoic and Proterozoic zircons from the Mid-Atlantic Ridge, Nature 393 (1998) 676-679.

[63] S.B. Shirey, J.F. Bender, C.H. Langmuir, Three component isotopic heterogeneity near the oceanographic transform, Mid-Atlantic Ridge, Nature 325 (1987) 217-223.

[64] J.J. Mahoney, W.M. White, B.G.J. Upton, C.R. Neal, R.A. Scrutton, Beyond EM-1 Lavas from Afanasy-Nikitin Rise and the Crozet Archipelago, Indian Ocean, Geology 24 (1996) 615. 
[65] S. Kodaira, R. Mjelde, K. Gunnarsson, H. Shiobara, H. Shimamura, Structure of the Jan Mayen microcontinent and implications for its evolution, Geophys. J. Int. 132 (1998) 383-400.

[66] J.E. Francis and M.F. Coffin, Cretaceous fossil wood from the Raggatt Basin, southern Kerguelen Plateau (Site 750), in: S.W. Wise, R. Schlich, et al., Proc. Ocean Drill. Prog., Scientific Results 120, Ocean Drill. Prog., College Station, TX, 1992, pp. 273-280.

[67] D.T. Sandwell, W.H.F. Smith, Marine gravity anomaly from Geosat and ERS-1 satellite altimetry, J. Geophys. Res. 102 (1997) 10039-10054.
[68] J.Y. Royer, N. Rollet, Plate tectonic setting of the Tasmanian region, Aust. J. Earth Sci. 44 (1997) 543-560.

[69] R.D. Müller, J.Y. Royer, L.A. Lawver, Revised plate motions relative to hotspots from combined Atlantic and Indian Ocean hotspot tracks, Geology 16 (1993) 275-278.

[70] R.G. Markl, Further evidence for the Early Cretaceous breakup of Gondwanaland off Southwestern Australia, Mar. Geol. 26 (1978) 41-48.

[71] H.M.J. Stagg, J.B. Willcox, A case for Australia-Antarctica separation in the Neocomian (ca. $125 \mathrm{Ma}$ ), Tectonophysics 210 (1992) 21-32. 